\title{
Oil-suspended particulate material aggregates as a tool in preventing potential ecotoxicological impacts in the São Paulo river, Todos os Santos Bay, Bahia, Brazil: Influence of salinity and suspended particulate material
}

\author{
Lorena S. Miranda $^{\mathrm{a}, *}$, Ícaro T.A. Moreira ${ }^{\mathrm{b}}$, Olívia M.C. Oliveira ${ }^{\mathrm{a}}$, Carlito P. Santos ${ }^{\mathrm{a}}$, Samires M.M. Pinheiro ${ }^{\mathrm{b}}$, \\ Lua M.L. Oliveira ${ }^{\mathrm{b}}$, Adriele B.O. Martins ${ }^{\mathrm{b}}$, Milton S.C. Filho ${ }^{\mathrm{b}}$ \\ a Núcleo de Estudos Ambientais, Instituto de Geociências, Universidade Federal da Bahia (UFBA), Campus de Ondina, 40170-290 Salvador, BA, Brazil \\ b EAETI, Universidade Salvador - UNIFACS, Avenida Cardeal da Silva, s/n, Prédio de Aulas 02, Salvador, BA, Brazil
}

\section{A R T I C L E I N F O}

Article history:

Received 5 July 2016

Accepted 17 August 2016

Available online 24 August 2016

\section{Keywords:}

Oil

Remediation

Oil-suspended particulate material aggregates (OSA)

Todos os Santos Bay

\begin{abstract}
A B S T R A C T
Recent studies have revealed the occurrence of a natural process of interaction between oil droplets and suspended particulate material, resulting in the formation of aggregates which are dispersed in the water column, known as oil-suspended particulate material aggregates (OSAs). The experiments aimed to investigate the contribution of OSAS in indicating where most likely is the oil sedimentation in the São Paulo river, Todos os Santos Bay, Brazil, in order to predict possible ecotoxicological risks caused by oil spills. The results showed that salinity and MPS concentration interfere on the formation of aggregates. In addition, the point 3 was nominated as the most vulnerable area to the potential ecotoxicological impacts of oil spills and should be treated as a priority area for the application of preventive and mitigating techniques.
\end{abstract}

(c) 2016 Elsevier Ltd. All rights reserved.

\section{Introduction}

Due to its composition, the oil can cause several environmental impacts, involving not only the fauna and flora, but also society (Sørensen, 2012; Dos Santos, 2012; Farias, 2008, p. 48 cited by Fundão et al., 2010). Because most of the activities associated with the oil being developed in coastal regions, these areas become more vulnerable to the impacts related to this compound (da Cruz, 2012; Miranda et al., 2014).

The oil spilled at any volume can cause impacts on the environment, whether immediate or long term, however, the severity of the damage, as well as the difficulty in recovery of the affected area may be influenced by several factors, including seasonality, the volume and the oil spilled characteristics, geographical location and biological factors (Garcia and La Rovere, 2011; Lopes et al., 2007; IPIECA, 2006; Lentz and Felleman, 2003; Dos Santos, 2012). It is estimated that, worldwide, about 5.74 million tons were discharged into the ocean between 1970 and 2014, as a result of incidents involving oil tankers (ITOPF, 2015). Thus, it is important to seek prevention and remediation measures in order to reduce the impacts.

Recent studies show that oil weathering processes help reduce environmental damage associated with spills in marine environments,

\footnotetext{
* Corresponding author.

E-mail address: lorenasuede@gmail.com (L.S. Miranda).
}

including the formation of aggregates between the oil and the suspended particulate material (Oil-Suspended Particulate Material Aggregate or OSA) (Colombo et al., 2005; Moreira, 2014; Silva, 2014). This formation helps to reduce the damages by natural processes of dispersion and/or acceleration of the biodegradation process, as the contact surface becomes larger and hence the oil being more available to the microorganisms of the environment (Moreira, 2014).

Then, considering that there are important characteristics that influence the OSA formation, this article presents a study of OSA formation focusing on salinity characteristics and concentration of suspended particulate material (SPM), aiming to investigate the contribution of OSA in the indication of the site most likely to oil sedimentation in the São Paulo river, Todos os Santos Bay, Bahia, in order to predict possible ecotoxicological risks caused by oil spills and allow the application of preventive techniques.

\section{Materials and methods}

The methodology was based on procedures, techniques and continuous literature review of issues associated with petroleum geochemistry and environment, remediation of contaminated areas by oil, characteristics and applications of OSAs, and so on. Also, it included the collection of samples in the area of interest, conducting laboratory experiments and the analysis and dissemination of results. 


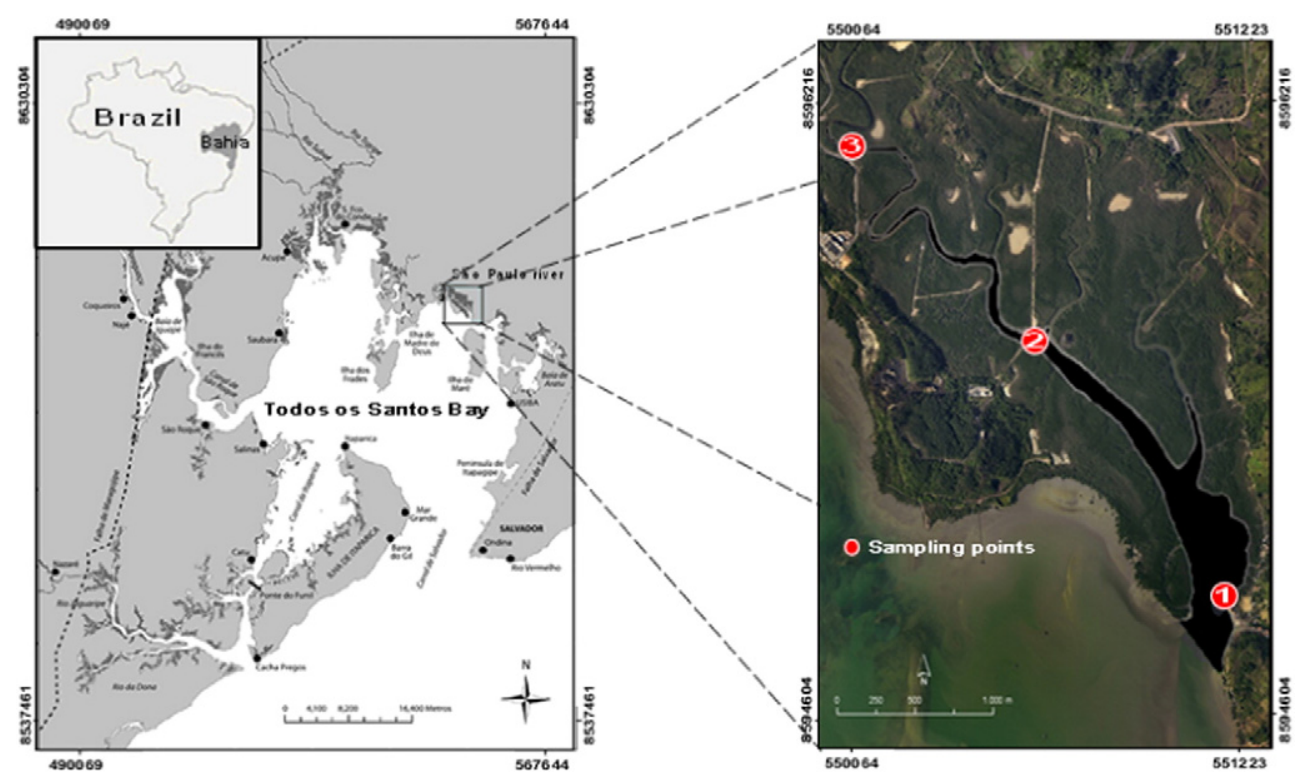

Fig. 1. Map of location of São Paulo river and points of sample collection. (Source: Adapted from Lessa et al. (2009)).

Table 1

Campos Basin oil properties.

\begin{tabular}{ll}
\hline Property & Results \\
\hline Density $(\rho)$ & $0,881,423 \mathrm{~g} \mathrm{~mL}^{-1}$ \\
Viscosity $(\eta)$ & $36,44 \mathrm{~m} \mathrm{~Pa} \mathrm{~s}^{-1}$ \\
Pristane & $160,878 \mathrm{mg} \mathrm{L}^{-1}$ \\
Phytane & $106,377 \mathrm{mg} \mathrm{L}^{-1}$ \\
PTH & $22,021,019 \mathrm{mg} \mathrm{L}^{-1}$ \\
UCM & $13,786,034 \mathrm{mg} \mathrm{L}^{-1}$ \\
\hline
\end{tabular}

\subsection{Study area}

The study area comprises the São Paulo river, located in the Todos os Santos Bay (TSB), Bahia, Brazil (Fig. 1). The area was chosen because it presents a contamination history associated with oil activities, and is a model area for several studies related to "Remediation of Impacted Areas by Oil", of the Federal University of Bahia (UFBA).

The estuary of the São Paulo river is located in the upper portion of Todos os Santos Bay, more precisely in the county of Candeias, metropolitan region of Salvador, Recôncavo Baiano. This river has great environmental and social relevance, being constantly subjected to environmental impact by being surrounded by various industrial activities and be close to towns and villages (Ramos, 2012).

Near the São Paulo river have been developed industrial activities, including oil refineries. Oil leaks occurrences have been recorded in the region (Jesus, 2011). Thus, investigating the formation of OSAS in this area is of great environmental, social and economic relevance.

\subsection{Sampling and pretreatment}

Samples were collected in July 2015, on the bank of three distinct points of the São Paulo river, being them the point 1, equivalent to the mouth, the point 2 located at an intermediate pier between points 1 and 3 , and point 3 , the nearest place of source possible of access. To collect the samples were used $20 \mathrm{~L}$ containers being collected $300 \mathrm{~L}$ of water in point 1, $260 \mathrm{~L}$ in point 2 and $240 \mathrm{~L}$ in point 3 . At each point a multiparameter probe was used to measure parameters such as $\mathrm{pH}$, salinity, dissolved oxygen and temperature. Containers were transported at room temperature and, when they reached the laboratory, were stored in refrigerated conditions.

In the laboratory, the $20 \mathrm{l}$ containers were allowed to stand in refrigerated conditions in order to decanting the particulate material. The water was then removed with the aid of silicone hoses and discarded

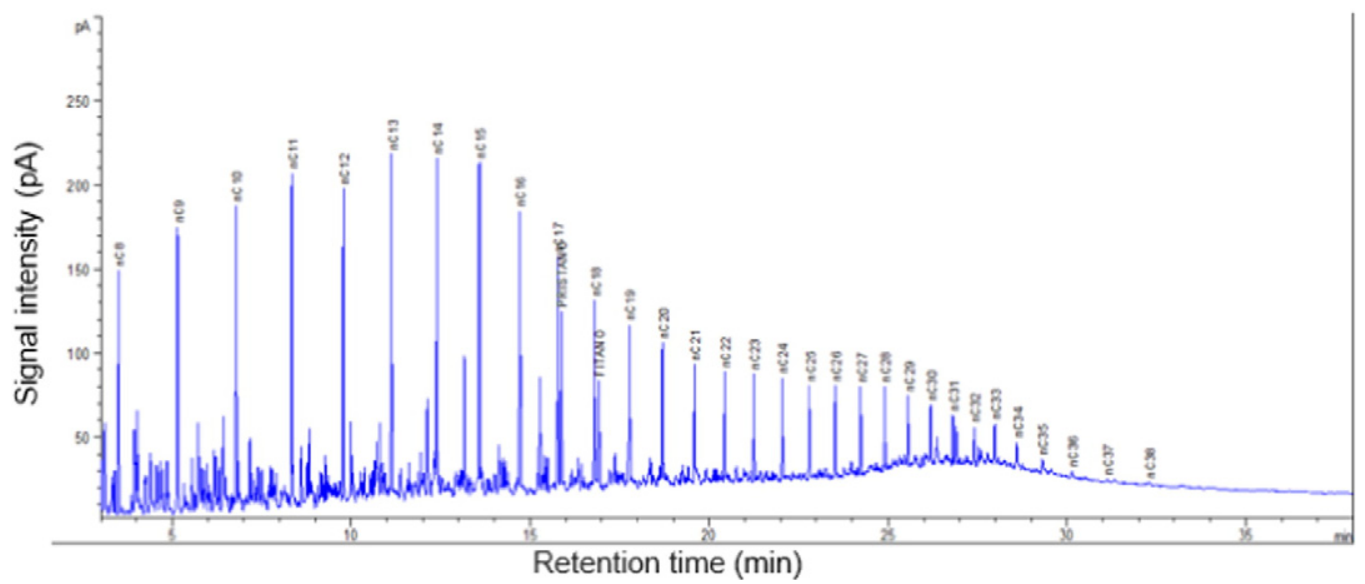

Fig. 2. Distribution profile of hydrocarbons in Campos Basin oil. 


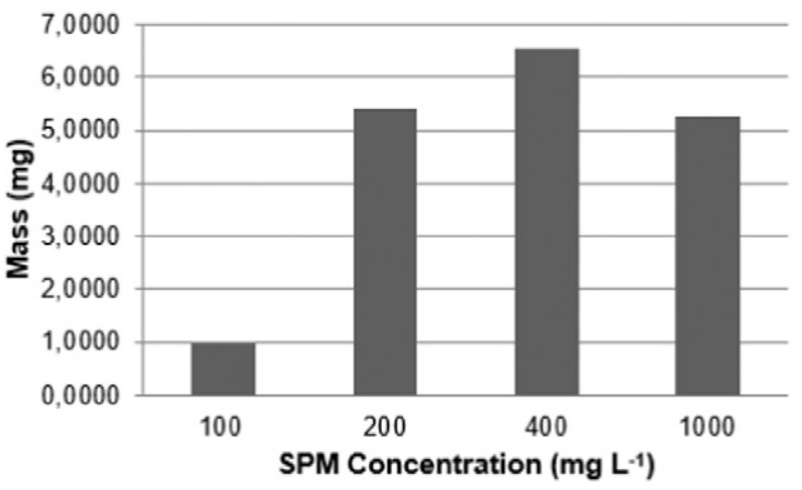

Fig. 3. Total dispersed oil to salinity 35 , with point 1 samples.

and the particulate material was transferred gradually to smaller glassware until they were in pre-weighed beakers. Then, the material was subjected to lyophilization.

\subsection{Oil characterization}

For the experiments were used the oil from the Campos Basin, whose density and viscosity properties were determined in the Environment Canada Laboratory (ASSUNÇÃO, 2014). Other characteristics were determined from gas chromatography with flame ionization detection (GC/FID) (Table 1). In Fig. 2 it is possible to observe the distribution profile of hydrocarbons in Campos oil.

\subsection{OSA formation experiment}

The experiments were performed in the Oil Studies Laboratory (LEPETRO), located in the Geosciences Institute (IGEO) of the Federal University of Bahia (UFBA).

The experiment was carried out in three distinct steps, according to the protocol developed by Moreira (2014), adapted from Khelifa et al. (2002). The two main objectives of these experiments were to determine aggregation capacity of the SPM collected in each of the three sampling points and optimize the amount of SPM used by determining the concentration of SPM causing a higher aggregation. SPM concentrations tested were $100 \mathrm{mg} \mathrm{L}^{-1}, 200 \mathrm{mg} \mathrm{L}^{-1}, 400 \mathrm{mg} \mathrm{L}^{-1}$ and $1000 \mathrm{mg} \mathrm{L}^{-1}$.

For all tests were used $50 \mathrm{mg}$ of oil. The experiment was conducted in three distinct series, corresponding to salinities 35 (with point 1 samples), 20 (with point 2 samples) and 10 (with point 3 samples). For each series were tested all SPM concentrations mentioned previously, in triplicate. In addition, tests were carried out with salinity 0 and tests without addition of SPM to observe more clearly the influence of salinity and of presence of SPM on the aggregates formation.

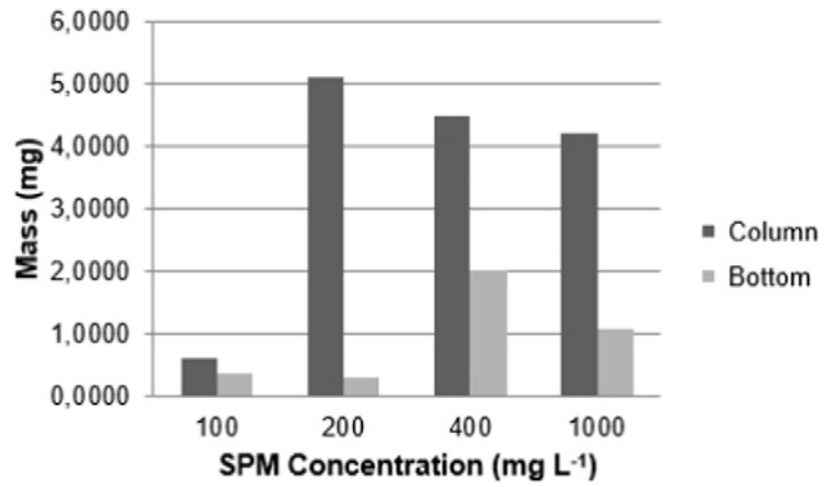

Fig. 4. Dispersed oil in the water column and bottom to salinity 35 , with point 1 samples.

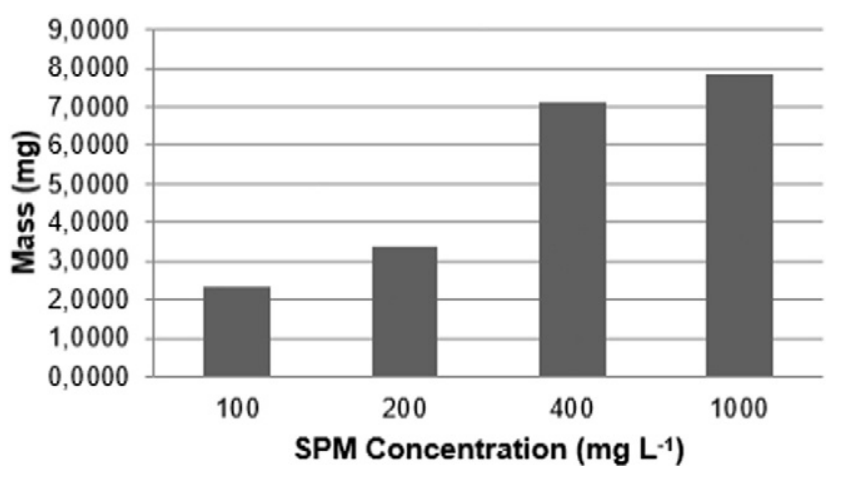

Fig. 5. Total dispersed oil to salinity 20 , with point 2 samples.

\subsubsection{Step 1}

In each test were added to $250 \mathrm{~mL}$ of artificial saline water and the corresponding amount of SPM to a $500 \mathrm{~mL}$ flask. Then the flasks were subjected to agitation in reciprocating shaker, model Marconi MA 570, for a minute, at the maximum speed, in order to moisturize the SPM, and left to stand for a period of approximately twelve hours.

\subsubsection{Step 2}

The flasks were subjected to agitation in reciprocating shaker for a minute, at the maximum speed, and then were added $50 \mathrm{mg}$ of oil with the aid of a micropipette. After this procedure, the flasks were once again subjected to agitation, this time for a period of three hours at approximately 126 cycles per minute. Then they were left to stand for approximately twelve hours.

\subsubsection{Step 3}

Were removed from each sample, aliquots of $50 \mathrm{~mL}$ from water column and bottom, carefully, to avoid disturbance. Then it was performed the liquid-liquid extraction to remove the material of interest of the analysis. The extraction was performed as described below.

1. Addition of the aliquot in $250 \mathrm{~mL}$ funnel;

2. Addition of $50 \mathrm{~mL}$ of dichloromethane;

3. Agitation of the funnel for $30 \mathrm{~s}$;

4. Vacuum filtration using glass microfibre membrane MN GF-2, with porosity of $0.5 \mu \mathrm{m}$ previously calcined, only phase present in the lower funnel after separation of the phases.

The procedures corresponding to steps 2, 3 and 4 were conducted three times for each sample. Then, the filtered material was transferred to a round bottom flask to pass by rotoevaporation and transferred to preweighed vials. The vials with the oil from the extraction were weighed again, getting the oil mas. After concentrated at a concentration of $0.05 \mathrm{mg} \mu \mathrm{L}^{-1}$, samples were submitted for analysis in gas

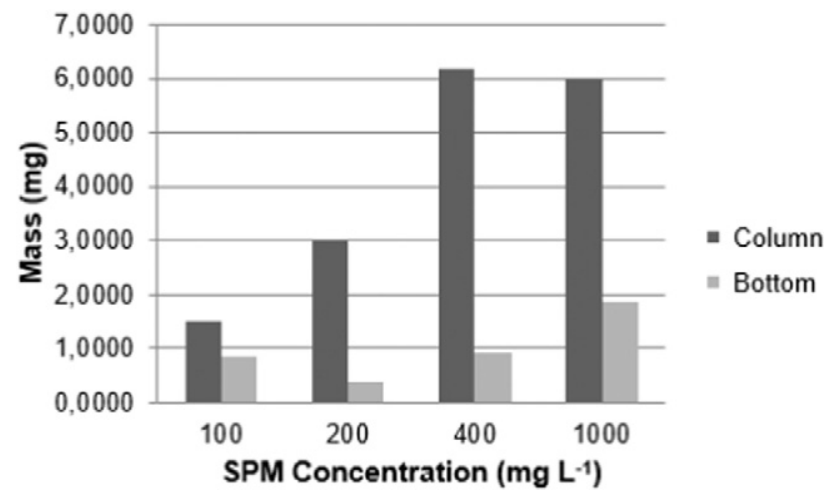

Fig. 6. Dispersed oil in the water column and bottom to salinity 20, with point 2 samples. 


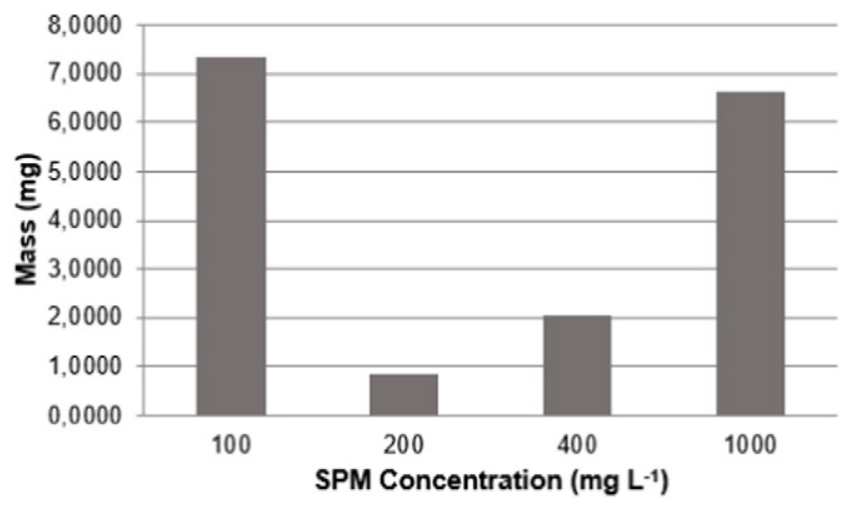

Fig. 7. Total dispersed oil to salinity 10 , with point 3 samples.

chromatograph, model Varian with capillary column DB-5 and flame ionization detector (GC-FID).

\subsection{Statistical analyses}

The analyzes of the results were made from descriptive statistics. Descriptive analysis was performed to identify outliers and data were summarized and shown in graphs and tables for better understanding and observation of the influence of the different parameters evaluated on the formation of OSA.

\section{Results and discussion}

From the results it is possible to observe that the salinity and SPM concentration had a significant impact on the OSA formation, however, should not be considered in isolation, as associated with other factors can show different results. For the data analysis, it was found that from the total of each sample, $50 \mathrm{~mL}$ corresponded to the surface, $150 \mathrm{~mL}$ corresponded to the column and $50 \mathrm{~mL}$ corresponded to the bottle.

\subsection{Salinity 35}

The results obtained using the salinity 35 for the different concentrations of SPM are shown in Fig. 3. In general, it is observed that, for a given salinity, increased SPM concentration favors the formation of OSAS, which is consistent with previous studies (Ajijolaiya et al., 2006; Rios, 2014; Sun and Zheng, 2009; Sun et al., 2010; Moreira, 2014). However, for the concentration $1000 \mathrm{mg} \mathrm{L}^{-1}$ the result did not follow this pattern. Schön (1996), says that different factors can influence the

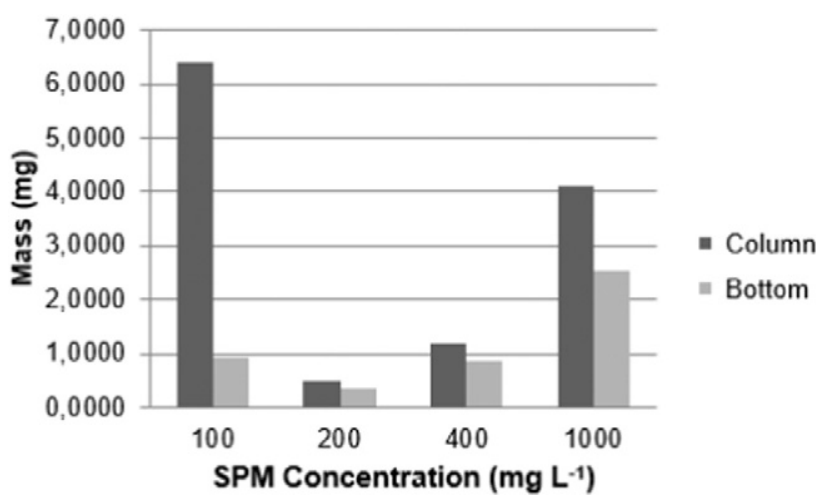

Fig. 8. Dispersed oil in the water column and bottom to salinity 10, with point 3 sample.

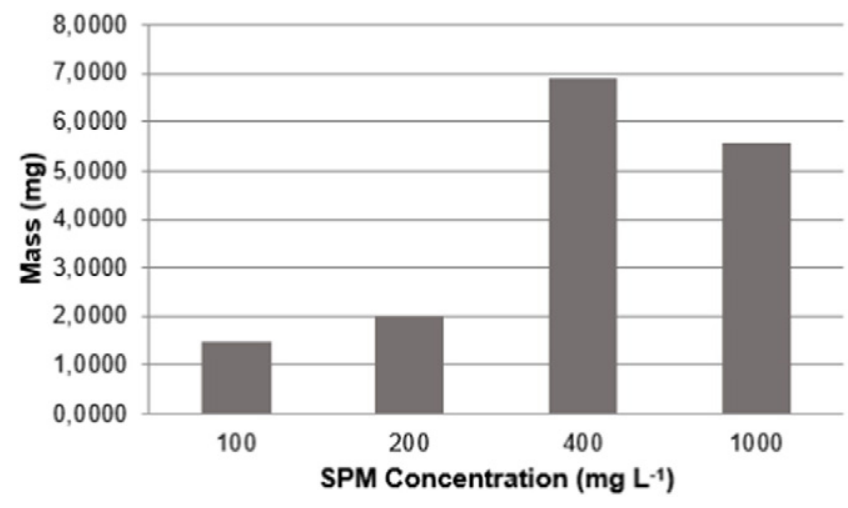

Fig. 9. Total dispersed oil using point 1 samples and salinity 0.

density of sediments, being porosity, mineral composition and saturation conditions.

Thus, in a higher concentration, SPM characteristics can have influenced the density such that the mixing energy applied was not enough to keep all the SPM in suspension (Ma et al., 2008; Rios, 2014; Wincele et al., 2004). Also, for all concentrations, it is noticed higher OSA formation in the water column compared to the bottom (Fig. 4), which is due to the fact that there are higher concentrations of SPM in the water column as a function of the energy which the samples were submitted.

Thus, from the results it is clear that, for salinity 35, using SPM samples collected at the mouth of the river São Paulo (point 1), the concentration of SPM of $400 \mathrm{mg} \mathrm{L}^{-1}$, is more favorable to the aggregates formation, representing, in relation to the total of dispersed oil, $68.88 \%$ in the water column and $31.12 \%$ in the bottom.

It is important to consider that, in spite of higher formation of aggregates in the water column, ideal condition for the faster biodegradation, greater amount of OSA is also formed in the bottom when compared to other concentrations. This can be attributed to the fact that a very high concentration of SPM, depending on their characteristics, may cause the aggregates to become too heavy, increasing the sedimentation rate (Zhang et al., 2010).

Despite the concentration of $400 \mathrm{mg} \mathrm{L}^{-1}$ have been more favorable to the formation of aggregates, concentration of $200 \mathrm{mg} \mathrm{L}^{-1}$ can be considered more favorable to oil biodegradation, as presented greater amount of oil in the water column, a region where microbial degradation tends to occur faster (Muschenheim and Lee, 2002), when compared to other tested concentrations.

\subsection{Salinity 20}

From Fig. 5 it is seen that the increase in SPM concentration favored the formation of OSAS, which is consistent with previous studies

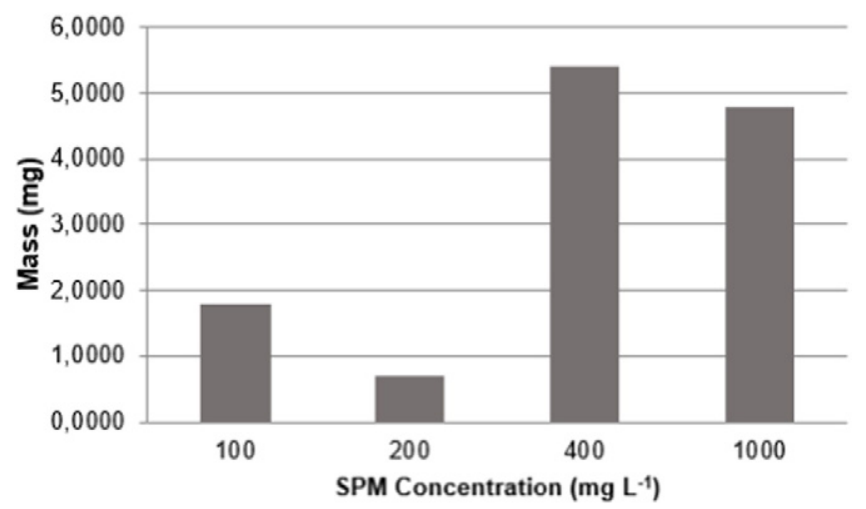

Fig. 10. Total dispersed oil using samples from point 2 and salinity 0 . 


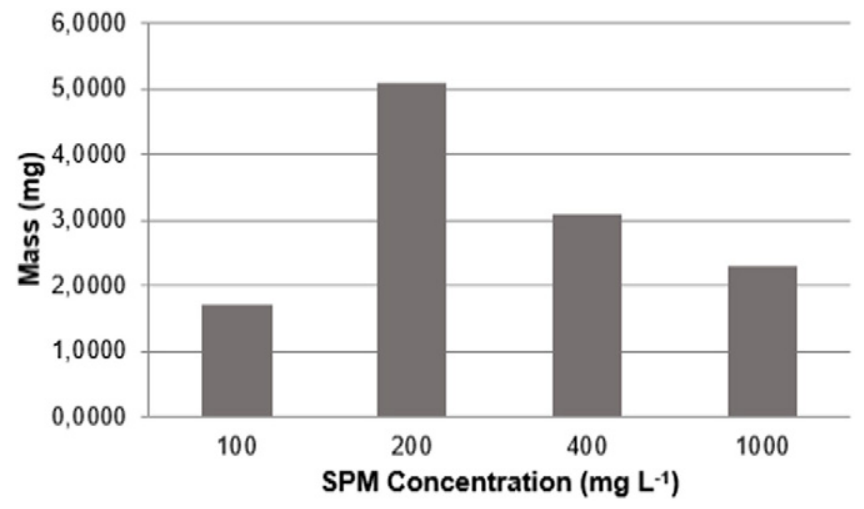

Fig. 11. Total dispersed oil using samples from point 3 and salinity 0 .

(Ajijolaiya et al., 2006; Moreira, 2014; Rios, 2014; Sun and Zheng, 2009; Sun et al., 2010). For tests with salinity 20 and SPM from point 2, the results showed that the concentration $1000 \mathrm{mg} \mathrm{L}^{-1}$ was more favorable to the formation of OSAS.

Fig. 6 shows that in all the tested concentrations there was increased formation of aggregates in the water column, which could be attributed to higher SPM concentration in this fraction due to the energy which the samples were submitted, which allowed the most SPM remained suspended. From the results it is clear that for salinity 20, using SPM samples collected in point 2 , equivalent to the pier, concentration $1000 \mathrm{mg} \mathrm{L}^{-1}$ was more favorable to the formation of aggregates with, in relation to the total dispersed oil, $76.27 \%$ in the water column and $23.73 \%$ in the bottom.

Again, it is important to consider that, in spite of increased formation of aggregates in the water column, which is the ideal condition, because the microbial degradation tends to occur faster (Muschenheim and Lee, 2002), a larger amount of OSA it is also formed in the bottom when compared to other concentrations. Thus, although the concentration $1000 \mathrm{mg} \mathrm{L}^{-1}$ have been more favorable to the formation of aggregates, concentration $200 \mathrm{mg} \mathrm{L}^{-1}$ can be considered more favorable to oil biodegradation, as showed higher amount of oil in the water column, compared to the other concentrations tested.

\subsection{Salinity 10}

For salinity 10 , there is a slightly different behavior when compared to salinities 20 and 35. Using SPM samples from point 3, associated with salinity 10 , it is clear that the lowest SPM concentration, corresponding to $100 \mathrm{mg} \mathrm{L}^{-1}$ was more favorable to OSA formation, even that, in general, the OSA formation had increased with increasing concentration of SPM (Fig. 7).

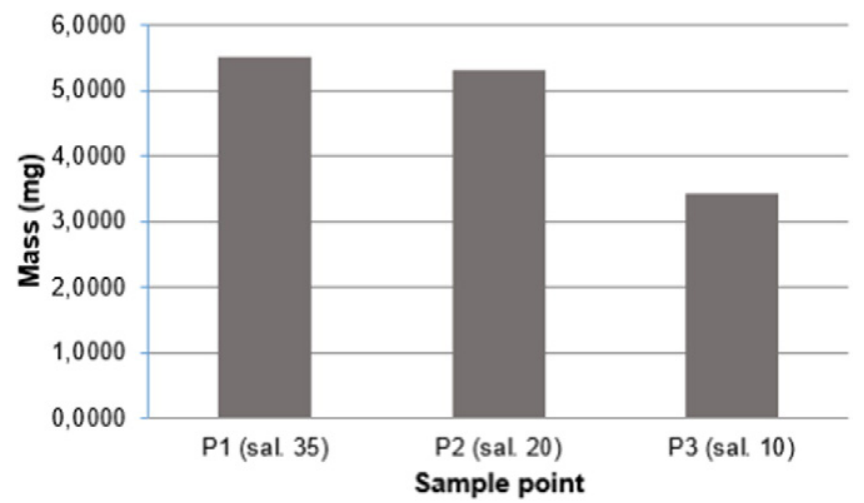

Fig. 12. Total dispersed oil without SPM addition with salinities 10, 20 and 35.

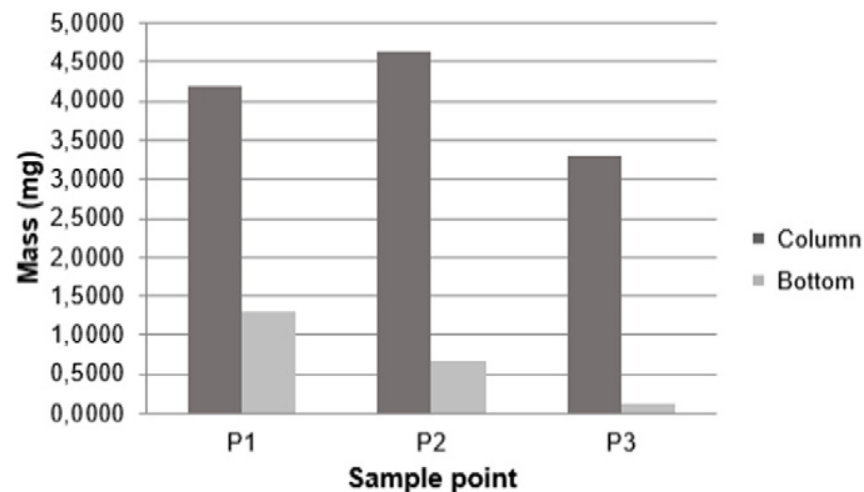

Fig. 13. Dispersed oil in the water column and bottom without SPM addition with salinities 10, 20 and 35 .

Considering the study of Schön (1996), it is possible that the point 3 SPM features have made that, at concentrations $200 \mathrm{mg} \mathrm{L}^{-1}$ and $400 \mathrm{mg} \mathrm{L}^{-1}$, the particles sank and were not available in the water column so that the shock and consequent formation of aggregates were not promoted. For the concentration $1000 \mathrm{mg} \mathrm{L}^{-1}$, the high SPM concentration may have caused, despite the high sedimentation rate due to SPM characteristics, the amount of particulate material which was kept in suspension has yet been sufficient to promote greater aggregation, compared to concentrations $200 \mathrm{mg} \mathrm{L}^{-1}$ and $400 \mathrm{mg} \mathrm{L}^{-1}$.

In all cases there was greater dispersion of oil in water column (Fig. 8). The results of the lowest and highest concentrations in relation to oil aggregation capacity were quite similar, but larger amount of oil in the bottom was present for the concentration $1000 \mathrm{mg} \mathrm{L}^{-1}$. Thus, for the salinity 10 , using samples collected from point 3 , were obtained best results, both for OSA formation and for better biodegradation condition, with concentration $100 \mathrm{mg} \mathrm{L}^{-1}$ representing, in relation to the total of dispersed oil, $87.27 \%$ in the water column and $12.73 \%$ in the bottom.

\subsection{Salinity 0 tests}

Tests with salinity 0 were performed in order to more clearly observe the effects of SPM on the OSA formation. Denominations P1, P2 and P3 refer to point 1, point 2 and point 3 samples, respectively. From Figs. 9, 10 and 11, it was observed that there was not a pattern of increased oil dispersion as it increased the SPM concentration, although for the points 1 and 2, higher concentrations have promoted greater aggregation.

In general, SPM samples from point 1 were more favorable to the OSA formation when used salinity 0 , followed by point 2 samples and, finally, point 3 samples. This behavior can be explained by higher concentrations of organic matter in points 1 and 2 and the lower concentration in point 3. Studies made by Moreira (2014), Floch et al. (2002), Guyomarch et al. (2002) and Khelifa et al. (2002) showed that there is a strong positive correlation between the organic matter and dispersion of oil from OSAS.

A higher concentration of organic matter favors the OSA formation, as it promotes the increase of interaction force that occurs between hydrocarbon and sedimentary particles, in function of the chemical affinity (Muschenheim and Lee, 2002). The concentration of organic matter may, further, increase the SPM density and contribute to increasing the aggregate sedimentation rate (Rios, 2014). Thus, in the absence of salts, organic matter becomes a significant factor in the formation of aggregates, however, it is important to consider other factors such as the SPM characteristics.

\subsection{Tests without SPM addition}

The tests without SPM addition were performed in order to more clearly observe the effect of salinity in the OSA formation. From the 


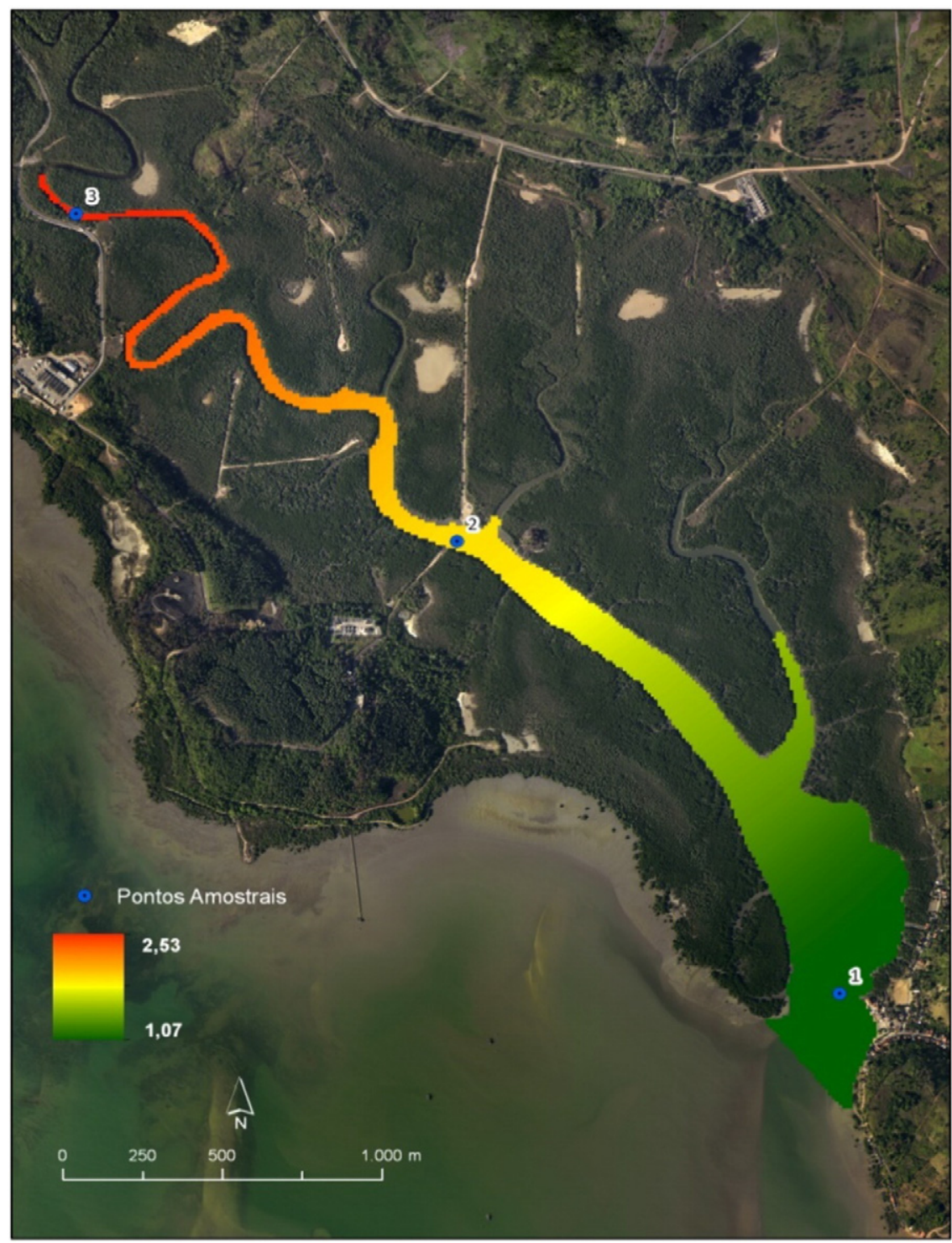

Fig. 14. Map of interpolation made by the Kernel method showing the variation in vulnerability to oil spills in São Paulo river.

results shown in Fig. 12, it is possible to verify that there was greater oil dispersion to salinity 35 , using the point 1 samples, followed by salinity 20 , with point 2 samples and, finally, salinity 10 , with point 3 samples. This result agrees with the results obtained by Moreira et al. (2015), Floch et al. (2002), Gong et al. (2014) and others, who claim that increased salinity favors the OSA formation. Thus, without adding MPS, salinity 35 was more favorable to the OSA formation. However, it is important to consider that, despite this, to salinity 35 there was also greater dispersion of oil in the bottom when compared with the other tested salinities. From Fig. 13, it is clear that for salinity 20, with samples from point 2, the oil biodegradation is more favored, as there was a greater dispersion in the water column, where microbial degradation tends to occur faster.

\subsection{Vulnerability to potential ecotoxicological impacts}

To assess the vulnerability to potential ecotoxicological impacts of oil spills, the values found in the bottom of each sample were analyzed, as in the real environment, besides impact benthic organisms, degradation tends to be much slower in the bottom. From the results, it was noticed that the point 3 is more vulnerable to possible ecotoxicological impacts of oil spills, followed by point 2 and, finally, point 1 (Fig. 14).
Thus, in case of oil spills in the São Paulo river, the region corresponding to point 3, closer to the source, should be treated as a priority area for the application of preventive and mitigating techniques followed by point 2 , in the intermediate section, and then, point 1 , corresponding to the mouth.

\section{Conclusion}

The OSA formation in São Paulo river is heavily influenced by salinity and SPM characteristics. Tests involving different salinities and SPM concentrations shown that, in general, the formation of OSAS tends to increase as SPM concentration increases and with higher salinities this formation is also favored. Although larger amounts of OSA, and consequent oil dispersion, have been formed in the water column, it should also consider the oil dispersion in the bottom, especially for higher SPM concentrations, as in the bottom degradation tends to be much slower and may impact benthic organisms.

It was concluded that, in relation to OSA formation capacity, point 2 is more favorable, followed by 1 point and finally point 3 . However, it is important to note that despite the impacts on planktonic and nektonic organisms, the ideal condition is that aggregates are remained in the water column to a faster degradation. Thus, comparing the dispersed 
oil values in the water column of all variations of salinity and SPM concentrations, point 2 is presented more favorable to oil biodegradation, followed by point 1 , and finally, point 3 .

Point 3 is more vulnerable to possible ecotoxicological impacts of oil spills, followed by point 2 and, finally, point 1 . Thus, in case of oil spills in São Paulo river, the region corresponding to point 3, closer to the source, should be treated as a priority area for the application of preventive and mitigation techniques, then point 2 , the intermediate part, and then the point 1 , corresponding to the mouth.

Applying salinity 0 there was no pattern of increase in oil dispersion as increased SPM concentration, although for the points 1 and 2, higher concentrations had promoted greater aggregation. Without SPM addition it was noted that the increase in salinity favored OSA formation. It is important to highlight that there is not always a pattern and, therefore, the characteristics have to be considered in an integrated way and never alone.

It should be pointed that the results were obtained based on the characteristics found at the time of collection, being important to carry out further studies which consider the environmental variations, for example, variations of the tides, and consequently, SPM concentrations, as the estuarine environments is very dynamic and undergoes constant changes in their characteristics. In this way, it will be possible to obtain much closer results to the reality.

\section{Acknowledgements}

This study has been carried out with the financial support of CNPq and CAPES.

\section{References}

Ajijolaiya, L.O., Hill, P.S., Khelifa, A., Islam, R.M., Lee, K., 2006. Laboratory investigation of the effects of mineral size and concentration on the formation of oil-mineral aggregates. Mar. Pollut. Bull. 52, 920-927.

Assunção, R.V., 2014. Investigação laboratorial da formação do agregado óleo-material particulado em suspensão do norte da Baía de Todos os Santos, BA, Brasil. Salvador, UFBA (59 p).

Colombo, J.C., Barreda, A., Bilos, C., Cappelletti, N., Migoya, M.C., 2005. Oil spill in the Rio de la Plata Estuary, Argentina: 2. Hydrocarbon disappearance rates in sediments and soils. Environ. Pollut. 267-276 n. 134.

Da Cruz, J.F., 2012. Avaliação da eficiência de surfactantes no processo de biodegradação de petróleo bruto em simulações de derrames no mar. Salvador, UFBA (76 p).

Dos Santos, P.V., 2012. Impactos ambientais causados pela perfuração de petróleo. Cadernos de graduação - ciências exatas e tecnológicas 1 (15), 153-163.

Farias Robson, Fernandes de, 2008. In: de Janeiro, Rio (Ed.), Introdução à química do petróleo. Ciência Moderna Ltda.

Floch, S.L., Guyomarch, J., Merlin, F.X., Stoffyn-Egli, P., Dixon, J., Lee, K., 2002. The influence of salinity on oil-mineral aggregate formation. Spill Sci. Technol. Bull. 8 (1), 65-71.

Fundão, A., Assmar, D., Dondoni, F., Santana, F., Falquete, R., 2010. Impactos ambientais do derramamento e petróleo. IFES, São Mateus (19 p).

Garcia, K.C., La Rovere, E.L., 2011. Petróleo: acidentes ambientais e riscos à biodiversidade. Interciência, Rio de Janeiro (232 p)
Gong, Y., Zhao, X., Cai, Z., O'reilly, S.E., Hao, X., Zhao, D., 2014. A review of oil, dispersed oil and sediment interactions in the aquatic environment: influence on the fate, transport and remediation of oil spills. Mar. Pollut. Bull. 79, 16-33.

Guyomarch, J., Floch, S.L., Merlin, F., 2002. Effect of suspended mineral load, water salinity and oil type on the size of oil-mineral aggregates in the presence of chemical dispersant. Spill Sci. Technol. Bull. 8 (1), 95-100.

IPIECA, (International Petroleum Industry Environmental Conservation Association), 2006n. Oil Spill Preparedness and Response Londres

ITOPF (International Tanker Owners Pollution Federation), 2015. Oil Tanker Spill Statistics 2014. (Londres)

Jesus, R.S., 2011. Metais traço em sedimentos e no molusco bivalve Anomalocardia brasiliana (Gmelin, 1791), municípios de Madre de Deus e de Saubara, Bahia. Salvador, UFBA (100 p).

Khelifa, A., Stoffyn-Egli, P., Hill, P.S., Lee, K., 2002. Characteristics of oil droplets stabilized by mineral particles: effects of oil type and temperature. Spill Sci. Technol. Bull. 8 (1), 19-30.

Lentz, S.A., Felleman, F., 2003. Oil Spill Prevention: A Proactive Approach International oil spill conference $(27 \mathrm{p})$

Lessa, G.C., Cirano, M., Genz, F., Tanajura, C.A.S., Silva, R.R., 2009. Oceanografia física. Baía de Todos os Santos: aspectos oceanográficos. EDUFBA, Salvador, pp. 67-120.

Lopes, C.F., Milanelli, J.C.C., Poffo, I.R.F., 2007. Ambientes costeiros contaminados por óleo: procedimentos de limpeza - manual de orientação. São Paulo, Secretaria de Estado do Meio Ambiente (120 p).

Ma, X., Cogswell, A., Li, Z., Lee, K., 2008. Particle size analysis of dispersed oil and oilmineral aggregates with an automated ultraviolet epi-fluorescence microscopy system. Environ. Technol. 29, 739-748.

Miranda, L.S., Anjos, J.A.S.A., Moreira, I.T.A., 2014. Avaliação de tecnologias de remediação em zonas costeiras impactadas pela indústria de petróleo. Revista eletrônica de energia 4 (1), 19-37.

Moreira, I.T.A., 2014. Investigação dos possíveis impactos ecológicos do petróleo sobre comunidades biológicas estuarinas na Baía de Todos os Santos e no sul da Bahia: OSA como uma ferramenta norteadora. 2014. 207 f Tese (Doutorado em Geologia) Universidade Federal da Bahia, Salvador.

Moreira, I.T.A., Oliveira, O.M.C., Silva, C.S., Rios, M.C., Queiroz, A.F.S., Assunção, R.V., Carvalho, A.P.N., 2015. Chemometrics applied in laboratory study on formation of oil-spm aggregates (OSAs) - a contribution to ecological evaluation. Microchem. J. $118,198-202$.

Muschenheim, D.K., Lee, K., 2002. Removal of oil from the sea surface through particulate interactions: review and prospectus. Spill Sci. Technol. Bull. 8 (1), 9-18.

Ramos Jr., A.B.S., 2012. Hidroquímica do rio São Paulo, Recôncavo Baiano. 2012. 72 f Dissertação (Mestrado em Geoquímica: Petróleo e Meio Ambiente) Universidade Federal da Bahia, Salvador.

Rios, M.C., 2014 Capacidade do sedimento do estuário do Paraguaçu-BA de formar agregado óleo-material particulado em suspensão (OSA). 2014. 65 f Monografia (Bacharelado em Oceanografia) Universidade Federal da Bahia, Salvador.

Schön, J.H., 1996. Physical properties of rocks: fundamentals and principles of petrophysics. Handbook of Geophysical Exploration: Seismic Exploration. 183600 p.

Silva, C.S., 2014. Potencial do OSA (agregado óleo-material particulado em suspensão) como agente de remediação em modelos de simulação de praias impactadas por petróleo. 2014. 107 f Dissertação (Mestrado em Geoquímica: Petróleo e Meio Ambiente) Universidade Federal da Bahia, Salvador.

Sørensen, L., 2012. Parameters Governing the Adsorption of Crude and Bunker Fuel Oils to Seawater Suspended Particulate Matter. NTNU, Trondheim (105 p).

Sun, J., Zheng, A.X., 2009. A review of oil-suspended particulate matter aggregation-a natural process of cleansing spilled oil in the aquatic environment. J. Environ. Monit. 11, 1801-1809.

Sun, J., Khelifa, A, Zheng X., Wang Z, So, L.L, Wong S., Yang C., Fieldhouse, B., 2010. A laboratory study of the kinetics of the formation of oil-suspended particulate matter aggregates using the NIST-1941b sediment. Mar. Pollut. Bull. 60, 1701-1707.

Wincele, D.E., Wrenn, B.A., Venosa, A.D., 2004. Sedimentation of oil-mineral aggregates for remediation of vegetable oil spills. J. Environ. Eng. 130, 50-58.

Zhang, H., Khatibi, M., Zheng, Y., Lee, K., Li, Z., Mullin, J.V., 2010. Investigation of OMA formation and the effect of minerals. Mar. Pollut. Bull. 60, 1433-1441. 